\title{
Klauzule wyłączające ochronę ubezpieczeniową w konsumenckiej umowie ubezpieczenia ochrony prawnej - uwagi na tle wyroku niemieckiego Trybunału Federalnego (Bundesgerichtshof) z 4 lipca 2018 roku
}

Niniejszy artykuł przedstawia wybrane uwagi do wyroku wydanego 4 lipca 2018 roku przez niemiecki Trybunał Federalny w sprawie o sygnaturze IVZR200/16 z zakresu ubezpieczenia ochrony prawnej. Trybunał uznał klauzulę wyłaczajaca ochronę ubezpieczeniowq stosowanq we wzorcowych warunkach ubezpieczenia ochrony prawnej (ARB 2008) za niejasna, a tym samym niewiqżqca konsumenta. Przy okazji tego wyroku poruszono niezwykle istotne z punktu widzenia praktyki ubezpieczeniowej kwestie zwiqzane z pojęciem wypadku ubezpieczeniowego. Prezentacji najważniejszych tez orzeczenia towarzyszq uwagi w przedmiocie obowiqzujacych regulacji prawa polskiego dotyczacych ubezpieczenia ochrony prawnej oraz treści wybranych ogólnych warunków polskich ubezpieczycieli ochrony prawnej. Autor artykułu odnosi się również do aktualnego orzecznictwa Sadu Najwyższego co do dyrektyw wykładni postanowień ogólnych warunków ubezpieczenia.

Słowa kluczowe: ubezpieczenie ochrony prawnej, wypadek ubezpieczeniowy, ogólne warunki ubezpieczenia, kodeks cywilny, ochrona konsumenta.

\section{Wstęp}

Niemiecki Trybunał Federalny (BGH) wielokrotnie wypowiadał się w sprawach z zakresu ubezpieczenia ochrony prawnej ${ }^{1}$. W ostatnim wyroku, wydanym w dniu 4 lipca 2018 roku, niemieccy sędzio-

1. Por. chociażby wyrok BGH z 20 lutego 1961 r., II ZR 139/59, NJW 1961, 1113 - dot. zakazu świadczenia pomocy prawnej przez ubezpieczycieli, por. M.-A. Lüth, Rechtsberatung durch den Rechtsschutzversicherer, Peter Lang GmbH, Frankfurt-Berlin-Berno-Nowy Jork-Paryż-Wiedeń 1997, s. 90 i nast.; wyrok BGH z 26 października 
wie poruszyli wiele wątków, również niezwiązanych bezpośrednio z prawem ubezpieczeniowym². Konieczność dogłębnej analizy różnorodnych aspektów sprawy wynikała ze złożonych okoliczności stanu faktycznego. Niniejszy artykuł, prezentujący uwagi do najważniejszych kwestii podkreślonych w omawianym wyroku, może być dla polskiej doktryny i praktyki ubezpieczeniowej inspiracja do spojrzenia na poruszane problemy z innej perspektywy.

W omawianej sprawie ubezpieczajacy zawarł w kwietniu 2010 roku umowę ubezpieczenia ochrony prawnej, a w grudniu 2014 roku zażądał od ubezpieczyciela potwierdzenia ochrony w zakresie pozasądowej realizacji interesów w sporze z bankiem. Spór dotyczył oświadczenia klienta banku (tj. ubezpieczającego) o odstapieniu $\left(\right.$ Widerruf) ${ }^{3}$ od umowy pożyczki ${ }^{4}$.

\section{Ubezpieczenie ochrony prawnej - ustawodawstwo i praktyka w Niemczech i Polsce}

Zgodnie z par. 125 niemieckiej ustawy o umowie ubezpieczenia ubezpieczyciel ochrony prawnej jest zobowiązany świadczyć wymagane usługi w umówionym zakresie w celu ochrony interesów prawnych ubezpieczającego lub ubezpieczonego ${ }^{5}$. W przepisie art. 27 ust. 1 ustawy o działalności ubezpieczeniowej i reasekuracyjnej polski ustawodawca skonstruował definicję legalną tego rodzaju ubezpieczenia. Polega ono na zobowiązaniu się zakładu ubezpieczeń w zamian za opłacenie składki ubezpieczeniowej do poniesienia kosztów postępowania sądowego oraz do wykonania innych usług związanych bezpośrednio z ochroną ubezpieczeniową, w szczególności w celu zapewnienia odszkodowania z tytułu poniesionej przez ubezpieczonego straty, szkody lub uszkodzenia ciała przez ugodę pozasądową lub w postępowaniu cywilnym lub karnym oraz obrony w postępowaniu karnym lub reprezentowania ubezpieczonego w postępowaniu cywilnym, karnym, administracyjnym lub innym postępowaniu lub w związku z roszczeniem zgłoszonym wobec tej osoby ${ }^{6}$. Należy zaznaczyć, że obie krajowe regulacje dotyczące ubezpieczenia ochrony prawnej czynią zadość obowiązkowi implementacji przepisów dyrektywy Solvency II?

1989 r., I ZR 242/87, NJW 1990, 578 oraz wyrok BGH z 4 grudnia 2013 r., IV ZR 215/12, NJW 2014, 630 - dot. swobody wyboru prawnika, por. Sz. Szmak Ubezpieczenie ochrony prawnej w Polsce na tle regulacji niemieckich, TNOiK, Toruń 2018, s. 146-148.

2. Wyrok w sprawie oznaczonej sygnaturą IV ZR 200/16 opublikowany m.in. w „Neue Juristische Wochenschrift” 2018, nr 2710.

3. Par. 355 i nast. niemieckiego kodeksu cywilnego - Bürgerliches Gesetzbuch (dalej: BGB) z 18 sierpnia 1896 r., Reichsgesetzblatt (dalej: RGBI.) S. 195, w wersji obwieszczenia z 2 stycznia 2002 r., Bundesgesetzblatt (dalej: BGBI.) I S. 42, 2909, 2003 I S. 738 ze zmianami.

4. Wyrok BGH o sygnaturze IV ZR 200/16, punkt 2 i 5.

5. Gesetz über den Versicherungsvertrag (VVG) z 30 maja 1908 r. w wersji po wejściu w życie nowelizacji z 23 listopada 2007 r., BGBI. I S. 2631, ze zmianami; por. szerzej: Sz. Szmak, op. cit., s. 74-77; por. także J. Cornelius -Winkler, Rechtsschutzversicherung. Ein Leitfaden für die Praxis, VVW, Karlsruhe 2008, s. 1.

6. Ustawa z dnia 11 września 2015 r., Dz. U. 2018, poz. 999 (tekst jedn.), por. E. Bukowska, Art. 27. Działalność ubezpieczeniowa [w:] Ustawa o działalności ubezpieczeniowej i reasekuracyjnej. Komentarz, [red.] P. Czablun, Warszawa 2016, Legalis; M. Krajewski, Art. 27 [w:] Ustawa o działalności ubezpieczeniowej i reasekuracyjnej. Komentarz, [red.] M. Szczepańska, P. Wajda, Warszawa 2017, LEX; Sz. Szmak, op. cit., s. 72-74.

7. Dyrektywa Parlamentu Europejskiego i Rady 2009/138/WE z dnia 25 listopada 2009 r. w sprawie podejmowania i prowadzenia działalności ubezpieczeniowej i reasekuracyjnej (Wypłacalność II), Dz. U. L nr 335, 
Umowa ubezpieczenia w przedmiotowej sprawie była zawarta na podstawie ogólnych warunków ubezpieczenia Allgemeine Rechtsschutz-Bedingungen (ARB) 2008. W tym miejscu należy przypomnieć o znaczeniu wzorcowych warunków ubezpieczenia w Niemczech. Od początku rozwoju nowoczesnej formy ubezpieczeń majątkowych w Niemczech aż po dzień dzisiejszy warunki te - w kolejnych wersjach - opracowane przez stowarzyszenie ubezpieczycieli niemieckich są stosowane przez większość zakładów ubezpieczeń w Niemczech ${ }^{8}$. Powyższe ma również zastosowanie do ubezpieczenia ochrony prawnej. Podkreślenia wymaga również fakt, że wcześniej warunki ARB odgrywały bardziej doniosłą rolę, ponieważ do 28 lipca 1994 roku niemieccy ubezpieczyciele mieli prawo do zawierania umów ubezpieczenia jedynie na podstawie ogólnych warunków zatwierdzonych przez organ nadzoru, ostatnimi z nich były warunki ARB 75. 29 lipca 1994 weszły w życie przepisy harmonizujące i liberalizujące prawo prywatne w ramach wspólnego rynku Unii Europejskiej i obowiązek ten zniesiono ${ }^{9}$. Na polskim rynku ubezpieczeń każdy z ubezpieczycieli posługuje się własnymi tekstami ogólnych warunków ubezpieczenia ${ }^{10}$.

Zgodnie z par. 2 ARB 2008 umowa ubezpieczenia obejmuje ochronę prawną w zakresie prawa umów i praw rzeczowych w celu ochrony interesów wynikających z zobowiązań prywatnoprawnych i praw rzeczowych. W par. 4 ust. 1 lit. c) przedmiotowych warunków sprecyzowano, że roszczenie o ochronę prawna powstaje po zajściu wypadku ubezpieczeniowego (Rechtsschutzfall) we wszystkich innych przypadkach (do których zalicza się omawiany spór z bankiem) od momentu, w którym ubezpieczający lub inna osoba dopuściła się lub miała się dopuścić naruszenia obowiązków lub przepisów prawa. Warunki te musza powstać po rozpoczęciu ochrony ubezpieczeniowej i przed jej zakończeniem. Zgodnie z par. 4 ust. 3 lit. a) (tzw. Vorerstreckungsklausel) ochrona prawna nie obowiązuje, gdy oświadczenie woli (Willenserklärung) lub czyn (Rechtshandlung) ${ }^{11}$ „powodujące” owo naruszenie miały miejsce przed rozpoczęciem ochrony ubezpieczeniowej.

17.12.2009 r., s. 1; por. Sz. Szmak Ubezpieczenie ..., s. 48-51; por. także wyroki Trybunału Sprawiedliwości Unii Europejskiej w przedmiocie swobody wyboru prawnika w ubezpieczeniu ochrony prawej o sygnaturach C-199/08, C-293/10, C-442/12, C-460/14 i C-5/15.

8. Por. aktualne wzorcowe warunki ubezpieczenia stowarzyszenia niemieckich ubezpieczycieli Gesamtverband der Deutschen Versicherungswirtschaft e.V. (GDV), https://www.gdv.de/de/ueber-uns/unsere-services/musterbedingungen-23924 [dostęp: 5.01.2019]; por. szerzej: Sz. Szmak, Ubezpieczenia ochrony prawnej w systemie niemieckim - wybrane problemy, „Wiadomości Ubezpieczeniowe” 2014, nr 2, s. 87-9?.

9. G. Bauer, J.C. Winkler, K. Maier, P. Stahl, W. Harbauer, Rechtsschutzversicherung: Kommentar zu den Allgemeinen Bedingungen für die Rechtsschutzversicherung (ARB 2000/2009 und 75], Begriffder Rechtsschutzversicherung, Beck, 2010, online - e-book [dostęp: 11.11.2011], Randnummer 20.; por. Sz. Szmak, Ubezpieczenie ..., s. 32-34.

10. Por. przykładowo: Ogólne Warunki Ubezpieczenia Ochrony Prawnej „Ochrona Prawna w Życiu Prywatnym” (OPŻP/ OPP/2018) przyjęte uchwałą Zarządu D. A.S. Towarzystwo Ubezpieczeń Ochrony Prawnej S. A. nr 02/05/2018 z dnia 8 maja 2018 r. (dalej: OWU DAS), Ogólne Warunki Ubezpieczenia Ochrony Prawnej OP/OWU/16/03 zatwierdzone uchwałą Zarządu Concordia Polska Towarzystwo Ubezpieczeń Wzajemnych z dnia 30 marca 2016 r. (dalej: OWU Concordia), Ogólne Warunki Ubezpieczenia PZU Dom ustalone uchwałą Zarządu Powszechnego Zakładu Ubezpieczeń S. A. nr UZ/261/2017 z dnia 13 września 2017 r., ze zmianami, Rozdział ? (dalej OWU PZU Dom).

11. Zachowanie człowieka wywołujące skutki prawne niezależnie od jego woli, w przeciwieństwie do czynności prawnej (Rechtsgeschäft), por. W. Flume, Allgemeiner Teil des Bürgerlichen Rechts: Das Rechtsgeschäft, Berlin-Heidelberg, 1992, s. 104-105. 


\section{Prawnoporównawcze uwagi szczegółowe}

W dniu 9 lipca 2008 roku powód zawarł z bankiem kilka umów pożyczki w celu sfinansowania nabycia gruntu, a następnie opłacił uzgodnione raty. Pismem pełnomocnika z dnia 10 grudnia 2014 roku powód zwrócił się do ubezpieczyciela z prośbą o potwierdzenie ochrony ubezpieczeniowej w zakresie pozasądowej ochrony interesów w związku z odstapieniem od jednej z tych umów. Zakład ubezpieczeń nie wyraził na to zgody. W dniu 20 marca 2015 roku powód odstapił od umowy pożyczki, podnosząc, że przysługuje mu to prawo z uwagi na niewłaściwe pouczenie w tym przedmiocie. Bank uznał oświadczenie klienta za spóźnione ${ }^{12}$.

Sąd I instancji, tj. Sąd Rejonowy w Kolonii (Amtsgericht Köln $)^{13}$ uznał żądanie powoda o potwierdzenie ochrony ubezpieczeniowej, zaś w wyniku apelacji pozwanego Sąd Krajowy w Kolonii (Landgericht Köln $)^{14}$ zmienił wyrok sądu I instancji i oddalił powództwo. Powód złożył rewizję (Revision ${ }^{15}$ do BGH w celu przywrócenia wyroku sądu I instancji.

Zgodnie ze stanowiskiem sądu odwoławczego powodowi nie przysługiwało roszczenie o ochronę ubezpieczeniową z uwagi na postanowienie klauzuli Vorerstreckungsklausel wyłączającej z zakresu ochrony ubezpieczeniowej spory, których istnienie miało być przesądzone przed zawarciem umowy ubezpieczenia. Zdaniem sadu krajowego klauzula ta ma zastosowanie w przypadku, gdy późniejszy spór prawny osiagnałłjuż tzw. pierwszy stopień realizacji zagrożenia. Oświadczenie woli lub czyn niesie za sobą „zalążek sporu prawnego” (Keim eines Rechtsstreites), jeśli jest w stanie spowodować naruszenie w znaczeniu par. 4 z ust. 1 zdanie 1 lit. c) ARB $2008^{16}$.

BGH stwierdził, że sąd odwoławczy słusznie oparł swoje rozstrzygnięcie na założeniu, iż za wypadek ubezpieczeniowy uznać należy wyrażoną przez bank odmowę ważności odstapienia ubezpieczającego od umowy pożyczki, ponieważ za najwcześniejszy moment należy uznać zachowanie, z którego ubezpieczajacy wywodzi swoje roszczenie ${ }^{17}$. Zdaniem BGH sąd odwoławczy również prawidłowo przyjał, że wadliwe (według oceny ubezpieczającego) pouczenie dot. prawa odstapienia nie stanowi wypadku ubezpieczeniowego zgodnie z par 4 ust. 1 zd. 1 lit. c) ARB 2008. Powód nie dąży bowiem do uzyskania prawidłowego pouczenia od banku, jego celem jest odstapienie od umowy pożyczki, a tym samym uznanie, że zachował właśnie takie uprawnienie. W związku z tym zarzucane bankowi przez ubezpieczającego naruszenie obowiązku należy łączyć dopiero z odmową uznania prawa odstapienia ${ }^{18}$.

12. Wyrok BGH o sygnaturze IV ZR 200/16, punkt 5-6.

13. Orzeczenie z 8 marca 2016 r.; sygnatura 124 C 483/15.

14. Orzeczenie z 14 lipca 2016 r.; sygnatura 24 S 10/16.

15. Por. par. 542 i nast. niemieckiego kodeksu postępowania cywilnego, Zivilprozessordnung z 30 stycznia 1877 r., Reichsgesetzblatt S. 83, w wersji obwieszczenia z 5 grudnia 2015 r., BGBI. I S. 3202; 2006 I S. 431; 2007 I S. 1781, ze zmianami.

16. Wyrok BGH o sygn. akt IV ZR 200/16, punkt 9 .

17. Wyrok BGH o sygn. akt IV ZR 200/16, punkt 18-19, por orzeczenia BGH z 25 lutego 2015 r., sygnatura IV ZR 214/14, Versicherungsrecht (dalej: VersR) 2015, 485; z 24 kwietnia 2013 r., sygnatura IV ZR 23/12, VersR 2013, 899; z 28 września 2005 r., sygnatura IV ZR 106/04, VersR 2005, 1684; z 19 marca 2003 r., sygnatura IV ZR 139/01, VersR 2003, 638; z 17 października 2007 r., sygnatura IV ZR 37/07, VersR 2008, 113.

18. Wyrok BGH o sygnaturze IV ZR 200/16, punkt 21 . 
Na gruncie prawa polskiego, zgodnie z art. 805 par. 1 kodeksu cywilnego ${ }^{19}$, ubezpieczyciel zobowiązuje się spełnić określone świadczenie w razie zajścia wypadku przewidzianego w umowie ${ }^{20}$. Z uwagi na redakcję tego przepisu przedstawiciele nauki prawa wyrażają od wielu lat potrzebę sformułowania całościowej definicji legalnej pojęcia wypadku ubezpieczeniowego ${ }^{21}$. Doktryna definiuje wypadek ubezpieczeniowy jako zdarzenie, od którego zależy powstanie obowiązku świadczenia zakładu ubezpieczeń ${ }^{22}$. W literaturze podkreśla się również fakt, że pojęcia zdarzenia losowego określonego w art. 3 ust. 1 pkt 57) ustawy o działalności ubezpieczeniowej i reasekuracyjnej nie należy utożsamiać z terminem wypadku ubezpieczeniowego ${ }^{23}$, a konieczność określenia wzajemnych relacji między tymi pojęciami jest postulowana przez przedstawicieli doktryny ${ }^{24}$.

W tym miejscu pożądana i wartościowa wydaje się prezentacja postanowień ogólnych warunków ochrony prawnej traktujących właśnie o wypadku ubezpieczeniowym na gruncie polskim.

Jeden z ubezpieczycieli warunkuje „ochronę prawną i reprezentację interesów prawnych” oraz „pokrycie kosztów, opłat i wydatków prawych” wystapieniem wypadku ubezpieczeniowego w okresie swojej odpowiedzialności ${ }^{25}$. Wypadek ubezpieczeniowy w przypadku „dochodzenia roszczeń lub w obronie przed roszczeniami wynikającymi z innych umów niż umowy ubezpieczenia, w tym z umów o pracę” jest przez niego definiowany jako „pierwsze naruszenie umowy lub przepisów prawa"26. Odpowiednikiem niemieckiej klauzuli Vorerstreckungsklausel jest postanowienie przedmiotowych warunków wyłączające odpowiedzialność ubezpieczyciela, jeżeli wypadki ubezpieczeniowe „wynikają ze zdarzenia, które wystapiło przed zawarciem umowy ubezpieczenia, a wypadek ubezpieczeniowy polegał na [...] zajściu zdarzenia będącego źródłem [...] naruszenia umowy"2?.

Kolejny z polskich ubezpieczycieli podobnie warunkuje istnienie ochrony ubezpieczeniowej „zajściem zdarzenia objętego ochroną ubezpieczeniową (wypadku ubezpieczeniowego) w okresie ubezpieczenia"28. Za moment wystapienia wypadku ubezpieczeniowego uważa się „moment, w którym Ubezpieczony, jego przeciwnik lub osoba trzecia zaczął naruszać lub domniemywa się, że zaczałł naruszać przepisy, obowiązki lub zobowiązania, które to naruszenie jest przyczyna problemu prawnego"29. Ubezpieczyciel ten wyłącza z ochrony wypadki ubezpieczeniowe, które

19. Ustawa z dnia 23 kwietnia 1964 r., Dz. U. 2018, poz. 1025 (tekst jednolity), dalej: k.c.

20. Por. szerzej: M Krajewski, Ubezpieczenie odpowiedzialności cywilnej według kodeksu cywilnego, Wolters Kluwer, Warszawa 2011, s. 166 i nast.

21. E. Kowalewski, O potrzebie zmian w kodeksowej regulacji w umowie ubezpieczenia, [w:] Zeszyt naukowy z okazji nadania tytułu doktora honoris causa Uniwersytetu Szczecińskiego Profesorowi Władysławowi Górskiemu, Wydawnictwo Naukowe Uniwersytetu Szczecińskiego, Szczecin 1993, s. 94-95.

22. M. Krajewski, Umowa ubezpieczenia. Art. 805-834 k.c. Komentarz, CH Beck, Warszawa 2004, s. 53 i nast.

23. D. Fuchs, Zakres obowiqzku prewencji w prawie ubezpieczeń gospodarczych. Uwagi na tle art. 826 k.c., „Prawo Asekuracyjne" 2004, nr 2 (39), s. 40 i nast. - uwagi autora dotyczą ówcześnie obowiązującej ustawy z dnia 22 maja 2003 r. o działalności ubezpieczeniowej. Dz. U. 2003, nr 124, poz. 1151.

24. A. Chróścicki, Umowa ubezpieczenia po nowelizacji kodeksu cywilnego. Komentarz, Wolters Kluwer, Warszawa 2008, s. 16-17; A. Wạsiewicz, E. Kowalewski, Postulowany kształt umowy ubezpieczenia w Kodeksie cywilnym, „Państwo i Prawo” 1993, nr 11-12, s. 6.

25. Par. 3 ust. 1 OWU DAS.

26. Par. 6 ust. 1 pkt 5) OWU DAS.

27. Par. 15 ust. 3 OWU DAS.

28. Par. 3 ust. 4 , par. 6 ust. 1 OWU Concordia.

29. Par. 6 ust. 2 pkt 5) OWU Concordia. 
„pozostają w związku z oświadczeniem woli albo ze zdarzeniami zaistniałymi przed rozpoczęciem ochrony ubezpieczeniowej" ${ }^{30}$. Należy zauważyć, że redakcja tego wyłączenia jest podobna do treści przedmiotowej klauzuli ARB 2008.

W ogólnych warunkach innego ubezpieczyciela działającego na polskim rynku sprecyzowano, że warunkiem jego odpowiedzialności jest „zajście wypadku ubezpieczeniowego w okresie ubezpieczenia”31. Wypadek ubezpieczeniowy w przypadku „sporów wynikających z umów innych niż dochodzenie roszczeń z tytułu gwarancji lub rękojmi” definiowany jest jako „pierwsze naruszenie postanowień umowy powodujące konieczność ochrony interesu prawnego ubezpieczonego"32.

\section{Konkluzje wyroku BGH}

Przechodząc do ostatecznego rozstrzygnięcia w omawianej sprawie, BGH uznał za błędne założenie sądu odwoławczego, że roszczenie powoda o ochronę ubezpieczeniowa jest nieuzasadnione z uwagi na postanowienia klauzuli Vorerstreckungsklausel. Treść klauzuli jest zdaniem BGH niejasna, a tym samym na podstawie par. 307 ust. 1 BGB jej postanowienia są bezskuteczne ${ }^{33}$. Zgodnie z tym przepisem postanowienia ogólnych warunków umowy są bezskuteczne, jeśli nadmiernie pogarszają sytuację prawna (benachteiligen) konsumenta w sposób sprzeczny z zasadami dobrych obyczajów. Takie nadmierne pogorszenie pozycji konsumenta może wynikać z faktu, że dane postanowienie nie jest jasne i zrozumiałe. Przytoczony przepis stanowi implementację art. 3 ust. 1 dyrektywy Rady 93/13/EWG z dnia 5 kwietnia 1993 roku w sprawie nieuczciwych warunków w umowach konsumenckich ${ }^{34}$. Stanowi on, że warunki umowy, które nie były indywidualnie negocjowane, mogą być uznane za nieuczciwe, jeśli stoją w sprzeczności z wymogami dobrej wiary, powoduja znaczącą nierównowagę wynikających z umowy, praw i obowiązków stron ze szkodą dla konsumenta. Wymóg transparentności został określony w treści art. 5 zd. 1 dyrektywy - w przypadku umów, w których wszystkie lub niektóre z przedstawianych konsumentowi warunków wyrażone są na piśmie, warunki te muszą zawsze być sporządzone prostym i zrozumiałym językiem.

Polski ustawodawca określił te warunki w kodeksie cywilnym, stanowiąc, że wzorzec umowy powinien być sformułowany jednoznacznie i w sposób zrozumiały ${ }^{35}$. Zaś postanowienia umowy zawieranej z konsumentem nieuzgodnione indywidualnie nie wiążą go, jeżeli kształtujajjego prawa i obowiązki w sposób sprzeczny z dobrymi obyczajami, rażąco naruszając jego interesy (niedozwolone postanowienia umowne]. Nie dotyczy to postanowień określających główne świadczenia stron, w tym cenę lub wynagrodzenie, jeżeli zostały sformułowane w sposób jednoznaczny ${ }^{36}$. Na marginesie omawianych przepisów warto przypomnieć o wciąż kontrowersyjnej w doktrynie

30. Par. 6 ust. 3 OWU Concordia.

31. Par. 51 ust. 3 PZU Dom.

32. Par. 2 pkt 132) lit. e) OWU PZU Dom.

33. Wyrok BGH o sygnaturze IV ZR 200/16, punkt 23.

34. Dz. U. L 95, 21.4.1993 r., s. 29-34.

35. Art. 385 par. 2 zd. 1 k.c.; por. np. P. Mikłaszewicz, Art. 385 k.c., [w:] Kodeks cywilny. Komentarz, [red.] K. Osajda, Legalis 2018.

36. Art. 385(1) par. 1 k.c.; por. A. Mlostoń-Olszewska, Rozdział I. Możliwość orzekania o uznaniu za niedozwolone postanowień wzorca umowy sprzecznych z bezwzględnie obowiqzujacymi przepisami prawa - argumenty za i przeciw, [w:] Prawo konsumenckie w praktyce, [red.] M. Czarnecka, T. Skoczny, Legalis 2016; por. także K. Szmak, Sz. 
Klauzule wyłączające ochronę ubezpieczeniową w konsumenckiej umowie ubezpieczenia ...

kwestii jednoznacznego określenia charakteru świadczenia głównego z umowy ubezpieczenia. Konsekwencja przyjęcia teorii wzajemności umowy ubezpieczenia jest uznanie, że świadczeniem z tej umowy po stronie ubezpieczyciela będzie ponoszenie ryzyka powstałej szkody ${ }^{37}$. Konkurencyjna teorią jest natomiast wskazanie zapłaty określonej sumy pieniężnej jako świadczenia głównego ubezpieczyciela, którą to tezę podzielił Sąd Najwyższy w wyroku z 20 października 2006 roku. ${ }^{38}$ Wydaje się, że biorąc pod uwagę całokształt przepisów prawa ubezpieczeniowego oraz specyfikę umowy ubezpieczenia, należy opowiedzieć się za stanowiskiem zwolenników teorii świadczenia pieniężnego ${ }^{39}$. Świadczeniem głównym ubezpieczyciela ochrony prawnej jest zapłata odszkodowania w postaci pokrycia „kosztów prawnych” objętych ochroną w danej umowie ubezpieczenia. Inne świadczenia wynikające z umowy (assistance prawne) trzeba będzie traktować jako świadczenia dodatkowe, których istnienie jest zależne od istnienia świadczenia głównego ${ }^{40}$.

BGH, uzasadniając swoje rozstrzygnięcie, stwierdził przede wszystkim, że przedmiotowa klauzula nie zawiera dodatkowej definicji wypadku ubezpieczeniowego. Stanowi ona natomiast niezależna, czasowo ograniczona przesłankę wyłączenia obowiązku świadczenia przez ubezpieczyciela, mająca na celu przeciwdziałanie zawieraniu umów ubezpieczenia ochrony prawnej na potrzeby uzyskania świadczenia z tytułu istniejących już sporów ${ }^{41}$. Zgodnie z nakazem transparentności (Transparenzgebot) prawa i obowiązki stron powinny by sformułowane w ogólnych warunkach umowy w sposób odpowiadający zasadom dobrych obyczajów (Treu und Glauben), tj. m.in. w sposób jasny i przejrzysty. Zrozumiałe dla przeciętnego ubezpieczającego sformułowanie treści danej klauzuli nie jest wystarczające dla spełnienia określonych powyżej wymogów. Zasady dobrych obyczajów nakazują również taką redakcję postanowienia, która pozwoli na ujawnienie gospodarczych niedogodności i obciążeń dla ubezpieczającego ${ }^{42}$.

W kontekście klauzul wyłączających ochronę ubezpieczeniową słuszny interes ubezpieczajacego powinien zostać zagwarantowany w taki sposób, że jedynie wówczas ubezpieczyciel nie będzie zapewniać ochrony, gdy dane wyłączenie pozostanie w zgodzie z oczywistym celem klauzuli. Według dyrektyw wykładni wynikających z utrwalonego orzecznictwa klauzule te należy interpretować w sposób wąski, aby ich cel gospodarczy został zachowany ${ }^{43}$.

BGH zauważył ponadto, że w treści klauzuli Vorerstreckungsklausel posłużono się pojęciami oświadczenia woli (Willenserklärung) i czynu (Rechtshandlung), których szeroka interpretacja

Szmak, VAT w kosztorysowej metodzie likwidacji szkód w autocasco, „Rzeczpospolita” 20.08.2013, https://www. rp.pl/artykul/1040392-VAT-w-kosztorysowej-metodzie-likwidacji-szkod-w-autocasco.html [dostęp: 12.01.2019].

37. Por. m. in. K. Malinowska, Komentarz do art. 805 Kodeksu cywilnego, [w:] Prawo ubezpieczeń gospodarczych. Komentarz. Tom II. Prawo o kontraktach w ubezpieczeniach. Komentarz do przepisów i wybranych wzorców umów, [red.] Z. Brodecki, M. Glicz, M. Serwach, LEX 2010; Z. Gawlik, Komentarz do art. 805 Kodeksu cywilnego, [w:] Kodeks cywilny. Komentarz. Tom III. Zobowiqzania - część szczególna, [red.] A. Kidyba, LEX 2010.

38. IV CSK 125/06, OSNC 2008, nr 1, poz. ?.

39. Sz. Szmak, Ubezpieczenie ..., s. 109.

40. Ibidem.

41. Wyrok BGH o sygnaturze IV ZR 200/16, punkt 24, por także wyrok BGH z 28 września 2005 r., sygnatura IV ZR 106/04, VersR 2005,1684.

42. Wyrok BGH o sygnaturze IV ZR 200/16, punkt 25, por. wyrok BGH z 9 maja 2001 r., sygnatura IV ZR 121/00, Entscheidungen des Bundesgerichtshofes in Zivilsachen (BGHZ) 147, 354.

43. Wyrok BGH o sygnaturze IV ZR 200/16, punkt 26, por. wyrok BGH z 17 grudnia 2008 r., sygnatura IV ZR 9/08, VersR 2009, 1147 oraz wyrok BGH z 17 marca 1999 r., sygnatura IV ZR 89/98, VersR 1999, 748. 
może kłócić się ze wspomnianą dyrektywą wąskiej wykładni zakresu klauzul wyłączających ochronę ubezpieczeniowa ${ }^{44}$. Trybunał wyraził poważne wạtpliwości, czy niuanse dotyczące omawianych pojęć są znane przeciętnemu ubezpieczającemu (laikowi prawnemu), to jego możliwości zrozumienia i interesy bierze się bowiem pod uwagę przy wykładni danych postanowieńn 45 .

Zgodnie z treścia przedmiotowej klauzuli ochrona prawna nie jest zapewniona, gdy oświadczenie woli lub czyn prawny podjęty przed początkiem okresu ubezpieczenia „powoduje” (auslösen] naruszenie. Zdaniem BGH taka redakcja postanowienia nie pozwala na w pełni zrozumiałe wyjaśnienie ubezpieczajacemu, w których konkretnie przypadkach ochrona ubezpieczeniowa jest wyłączona ${ }^{46}$. Bezspornym jest jedynie fakt, że mowa tu o zdarzeniu stanowiącym przyczynę późniejszego naruszenia ${ }^{4 ?}$. W orzecznictwie i literaturze wskazuje się na dodatkowe wymagania dotyczące związku przyczynowego w klauzuli Vorerstreckungsklausel. Nie jest wystarczający jedynie adekwatny związek przyczynowy pomiędzy oświadczeniem woli lub czynem a późniejszym naruszeniem. Zachowanie powodujące naruszenie musi zawierać w sobie wspomniany „zalaż̇ek sporu prawnego"48. Przeciętny ubezpieczający bez wykształcenia prawniczego nie ma obowiązku odróżnienia „zalążka późniejszego sporu prawnego” lub „pierwszego etapu realizacji ryzyka” od zwykłej przyczyny ${ }^{49}$. BGH przypomina, że w orzecznictwie i literaturze nie udało się do tej pory opracować abstrakcyjnych kryteriów wykładni terminu „auslösen” ${ }^{50}$. W orzecznictwie znaleźć można jedynie kazuistyczne przykłady takich zachowań, jak np. złożenie wniosku o świadczenie lub zgłoszenie szkody do ubezpieczyciela następstw nieszczęśliwych wypadków ${ }^{51}$, czy wyrażenie żądania w związku z podwyżką czynszu najmu ${ }^{52}$. Do grupy tej niemieckie orzecznictwo nie zalicza natomiast wypowiedzenia umowy w kontekście późniejszych sporów dotyczących rozliczeń ${ }^{53}$, braku płatności podwyższonego czynszu najmu ${ }^{54}$ oraz obietnicy testamentowego uregulowania wynagrodzenia za świadczenia pielęgnacyjne ${ }^{55}$. Zdaniem BGH właśnie ta czysto abstrakcyjna konstrukcja klauzuli sprawia, że ubezpieczający nie jest wystarczająco poinformowany, jakie luki w ochronie ubezpieczeniowej będą konsekwencją określonych wyłączeń56 ${ }^{5}$

44. Wyrok BGH o sygn. akt IV ZR 200/16, punkt 29-302 por. orzeczenia Wyższego Sądu Krajowego w Kolonii z 15 stycznia 2016 r., 9 U 251/15, VersR 2017, 484, 486 oraz z 2 maja 2016 r., sygnatura 9 U 252/15.

45. Wyrok BGH o sygnaturze IV ZR 200/16, punkt 36.

46. Wyrok BGH o sygnaturze IV ZR 200/16, punkt 38.

47. Wyrok BGH o sygnaturze IV ZR 200/16, punkt 39.

48. Wyrok BGH o sygn. akt IV ZR 200/16, punkt 44, por. wyrok BGH z 17 stycznia 2007 r., sygnatura IV ZR 124/06 , VersR 2007, 535, z 28 września 2005 r., IV ZR 106/04, VersR 2005, 1684.

49. Wyrok BGH o sygnaturze IV ZR 200/16, punkt 45.

50. Wyrok BGH o sygnaturze IV ZR 200/16, punkt 46.

51. Por. uwagi przewodniczącego IV Izby Cywilnej (Zivilsenat) BGH z 5 kwietnia 2006 r., sygnatura IV ZR 176/05, Beck online Rechtsprechung (BeckRS) 2013, 11723, wyrok Sądu Rejonowego w Hanowerze, sygnatura 565 C 12080/98, r+s 2000, 378, wyrok Sądu Rejonowego w Karlsruhe, sygnatura ? C 535/95, r+s 1997, 71.

52. Wyrok Sądu Krajowego w Kolonii, ZfSch 1991, 20.

53. Wyrok Sądu Rejonowego w Mönchengladbach, sygnatura 2 a C 14/88, r+s 1988, 300.

54. Wyrok Wyższego Sądu Krajowego w Hamm, sygnatura 20 U 123/91, VersR 1992, 734.

55. Wyrok Wyższego Sądu Krajowego w Kolonii, ZfSch 2001, 514.

56. Wyrok BGH o sygnaturze IV ZR 200/16, punkt 48; w związku z omawianym wyrokiem niektórzy niemieccy prawnicy sugerowali szybkie zawarcie umów ubezpieczenia ochrony prawnej, aby objać ochroną ubezpieczeniową umowy istniejące przed rozpoczęciem okresu ubezpieczenia - np. Laux Rechtsanwälte, BGH kippt 


\section{Ochrona ubezpieczającego będącego konsumentem w Polsce}

W podsumowaniu warto tę prokonsumencką postawę niemieckiego Trybunału Federalnego skonfrontować z realiami polskimi. W sposób oczywisty należy wziać pod uwagę istotne różnice i specyfikę rynku ubezpieczeniowego w Niemczech. Jak już wspomniano, większość niemieckich ubezpieczycieli posługuje się tym samym wzorcem warunków ubezpieczenia, stąd omawiany wyrok ma bezpośredni wpływ na niebagatelną liczbę ubezpieczonych. Cechą charakterystyczną praktyki ubezpieczeniowej w Niemczech jest również zawieranie umów ubezpieczenia z dość długim okresem wypowiedzenia, przez co umowy z reguły „przedłużają się” co roku, a tym samym ważność ogólnych warunków ubezpieczenia będących podstawą zawarcia danej umowy nadal trwa. W Polsce powszechna praktyką jest zawieranie umów ubezpieczenia na czas określony, najczęściej z rocznym okresem ubezpieczenia. W takim przypadku istnieje większe prawdopodobieństwo zmiany ubezpieczyciela, a tym samym warunków mających zastosowanie do nowej umowy ubezpieczenia. Wydaje się zatem, że niemiecki rynek ubezpieczeniowy cechuje większa pewność i stabilność.

Odnosząc się do tez BGH sformułowanych w omawianym wyroku, należy stwierdzić, że w podobny sposób wypowiada się od lat polski Sąd Najwyższy (SN) ${ }^{5}$. Wykładnia postanowień ogólnych warunków ubezpieczenia (OWU) nie może pomijać celu, w jakim umowa ubezpieczenia została zawarta, a także natury i funkcji zobowiązania, a celem tej umowy jest udzielenie ubezpieczonemu ochrony w razie wystapienia określonego ryzyka. Dlatego też postanowienia OWU powinny precyzyjnie określać postacie ubezpieczonego ryzyka, a w razie niejasności czy watpliwości także co do wzajemnej relacji między tym postanowieniami należy z mocy art. 385 par. 2 k.c. interpretować je na korzyść ubezpieczającego ${ }^{58}$, przy uwzględnieniu reguł określonych w art. 65 par. 2 k.c. ${ }^{59}$ Ponadto ryzyka objęte ubezpieczeniem i przesłanki wyłączenia odpowiedzialności ubezpieczyciela powinny być zarówno w umowie, jak i w OWU jednoznaczne i wyraźnie określone, aby ubezpieczający wiedział, jakie zdarzenia nie są objęte ubezpieczeniem. Konsekwencje postanowień OWU zawierających uregulowania niejasne, wieloznaczne, mylące i obiektywnie niezrozumiałe dla przeciętnego adresata ponosi ubezpieczyciel jako twórca wzorca umowy ${ }^{60}$. Umowa ubezpieczenia należy do umów szczególnego zaufania, a jej postanowienia oraz postanowienia OWU ubezpieczyciela powinny być jasne, zrozumiałe i jednoznaczne, aby ubezpieczajacy przed jej zawarciem miał świadomość ryzyk, które nie są objęte ubezpieczeniem, oraz przesłanek, które ograniczają lub wyłączaja odpowiedzialność ubezpieczyciela ${ }^{61}$. Najważniejsze tezy zaprezentowanego orzecznictwa

Vorerstreckungsklausel im Rechtsschutzvertrag https://www.ra-laux.de/bgh-kippt-vorstreckungsklausel-im -rechtsschutzvertrag/ [12.01.2019].

57. Por. niedawny wyrok SN z dnia 14 marca 2018 r., II CSK 445/17, Baza Orzeczeń SN, http://www.sn.pl/ orzecznictwo/SitePages/Baza_orzeczen.aspx? ItemSID=27681-57 a0 abe2-a?3c-441d-9691b79a0c36be5c\&ListName=Orzeczenia3 [dostęp: 12.01.2019].

58. Wyrok SN z dnia 13 maja 2004 r., V CK 481/03, niepublikowany.

59. Wyrok SN dnia 2 kwietnia 2014 r., IV CSK 420/13, niepublikowany, postanowienie SN z dnia 13 czerwca 2013 r., IV CNP 80/12, niepublikowane; wyrok SN z dnia 2 grudnia 1998 r., I CKN 278/98, niepublikowany; postanowienie SN z dnia 22 lipca 2005 r., III CZP 49/05, niepublikowane.

60. Wyrok SN z dnia 12 stycznia 2007 r., IV CSK 307/06, niepublikowany.

61. Wyrok SN z dnia 15 stycznia 2016 r., I ICSK 122/15, niepublikowany. 
znalazły swój wyraz w odpowiednich przepisach ustawy o działalności ubezpieczeniowej i reasekuracyjnej, w art. 15 ust. 3 oraz 5.

\section{Wnioski końcowe}

Podejmując próbę oceny transparentności przytoczonych wcześniej postanowień warunków polskich ubezpieczycieli ochrony prawnej z perspektywy omawianego wyroku, należy stwierdzić, że podobnie jak w przypadku niemieckich warunków ARB 2008 polskie zakłady ubezpieczeń posługują się pojęciami, które dla przeciętnego ubezpieczającego będącego konsumentem moga sprawiać wrażenie niejasnych i niezrozumiałych. Wydaje się, że ubezpieczyciele używając sformułowań: „wypadek wynikajacy ze zdarzenia”, „źródło naruszenia umowy”62, czy „wypadki ubezpieczeniowe, które pozostają w związku z oświadczeniem woli albo ze zdarzeniami zaistniałymi przed rozpoczęciem ochrony ubezpieczeniowej" ${ }^{63}$, nie czynią zadość dyrektywom wypracowanym przez polskie orzecznictwo. W tym miejscu nie jest jednak wskazane teoretyczne rozważenie, jaki kształt przyjęłoby możliwe analogiczne rozstrzygnięcie polskiego sądu i które przepisy byłyby podstawą takiego orzeczenia. Oczywistym jest, że ogromne znaczenie mają okoliczności konkretnej sprawy i ich wpływ na prawną kwalifikację danego przypadku.

W kontekście poruszanych w niniejszym artykule zagadnień nie sposób nie wspomnieć o niedawnej implementacji do polskiego porządku prawnego postanowień unijnej dyrektywy w sprawie dystrybucji ubezpieczeń ${ }^{64}$. Niektórzy przedstawiciele doktryny określaja przepisy obowiązującej od 1 października 2018 roku ustawy ${ }^{65}$ jako swoistą rewolucję legislacyjną na polskim rynku ubezpieczeń. Z jednej strony wskazuje się na brak spójności, w szczególności systemowej, nowych unormowań z istniejącymi aktami prawnymi składającymi się na obowiązujące w Polsce prawo ubezpieczeń gospodarczych ${ }^{66}$, z drugiej zaś - na wzrastający poziom ochrony klientów-podmiotów słabszych w relacjach ubezpieczeniowych, równoległej i podmiotowo szerszej wobec tej wynikającej z przepisów kodeksowych ${ }^{6}$. Jedynie na gruncie przepisu art. 8 ust. 3 ustawy o dystrybucji ubezpieczeń pojawiają się w doktrynie - i niewątpliwie pojawią na etapie sądowych sporów pomiędzy stronami umowy ubezpieczenia - różne interpretacje określonego w tym przepisie wymogu zgodności umowy ubezpieczenia z potrzebami klienta w zakresie ochrony ubezpieczeniowej. Wypracowanie ugruntowanej linii orzeczniczej w przedmiocie wykładni budzących wạtpliwości nowych przepisów oraz staranna nowelizacja ustawy o dystrybucji ubezpieczeń niwelująca pojawiające się zagrożenia leżą w interesie wszystkich podmiotów polskiego rynku ubezpieczeń.

62. Par. 15 ust. 3 OWU DAS.

63. Par. 6 ust. 3 OWU Concordia.

64. Dyrektywa Parlamentu Europejskiego i Rady (UE) 2016/97 z dnia 20 stycznia 2016 r., Dz.Urz. UE L 26 z 02.02.2016 r., s. 19-59.

65. Ustawa z dnia 15 grudnia 2017 r. o dystrybucji ubezpieczeń, Dz. U., 2018, poz. 2210, 2243 (tekst jednolity).

66. Por. szerzej: J. Pokrzywniak, Problem spójności ustawy o dystrybucji ubezpieczeń z dotychczasowym polskim ustawodawstwem ubezpieczeniowym, [w:] 0 dobre prawo dla ubezpieczeń. Księga Jubileuszowa Profesora Eugeniusza Kowalewskiego, [red.] E. Bagińska, W. Mogilski, M. Wałachowska, M. Ziemiak,Toruń 2019, s. 265-278.

67. Zob. M. Orlicki, 0 zaniku konsumenckiego prawa ubezpieczeniowego, [w:] 0 dobre prawo dla ubezpieczeń..., s. $257-264$. 
Klauzule wyłączające ochronę ubezpieczeniową w konsumenckiej umowie ubezpieczenia ...

Najważniejszym dla polskiego rynku ubezpieczeniowego wnioskiem, który powinien być adresowany przede wszystkim do twórców ogólnych warunków ubezpieczenia, jest postulat dbałości o większą przejrzystość stosowanych we wzorcach umownych sformułowań, w szczególności w postanowieniach stanowiących o wyłączeniach ochrony ubezpieczeniowej. Zastosowanie się do tej sugestii oddaliłoby stawiany zakładom ubezpieczeń zarzut celowego braku doprecyzowania niekorzystnych dla ubezpieczającego postanowień. Ma to istotne znaczenie w przypadku ubezpieczenia ochrony prawnej, które spełnia także ważną rolę w dostępie obywateli do wymiaru sprawiedliwości68.

\section{Wykaz źródeł:}

Bauer G., Winkler J. C., Maier K., Stahl P., Harbauer W., Rechtsschutzversicherung: Kommentar zu den Allgemeinen Bedingungen für die Rechtsschutzversicherung (ARB 2000/2009 und 75), CH Beck, 2010, online - e-book.

Chróścicki A., Umowa ubezpieczenia po nowelizacji kodeksu cywilnego. Komentarz, Wolters Kluwer, Warszawa 2008.

Cornelius-Winkler J., Rechtsschutzversicherung. Ein Leitfaden für die Praxis, VVW, Karlsruhe 2008. Flume W., Allgemeiner Teil des Bürgerlichen Rechts: Das Rechtsgeschäft, Springer, Berlin-Heidelberg 1992.

Fuchs D., Zakres obowiqzku prewencji w prawie ubezpieczeń gospodarczych. Uwagi na tle art. 826 k.c., „Prawo Asekuracyjne” 2004, nr 2 (39).

Kodeks cywilny. Komentarz, Osajda K. [red.], Legalis 2018.

Kodeks cywilny. Komentarz. Tom III. Zobowiqzania - część szczególna, Kidyba A. [red.], LEX 2010. Kowalewski E., O potrzebie zmian w kodeksowej regulacji w umowie ubezpieczenia, [w:] Zeszyt naukowy z okazji nadania tytułu doktora honoris causa Uniwersytetu Szczecińskiego Profesorowi Władysławowi Górskiemu, Wydawnictwo Naukowe Uniwersytetu Szczecińskiego, Szczecin 1993. Krajewski M., Ubezpieczenie odpowiedzialności cywilnej według kodeksu cywilnego, Wolters Kluwer, Warszawa 2011.

Krajewski M., Umowa ubezpieczenia. Art. 805-834 k.c. Komentarz, CH Beck, Warszawa 2004. Laux Rechtsanwälte, BGH kippt Vorerstreckungsklausel im Rechtsschutzvertrag.

Lüth M.-A., Rechtsberatung durch den Rechtsschutzversicherer, Peter Lang GmbH, FrankfurtBerlin-Berno-Nowy Jork-Paryż-Wiedeń 1997.

O dobre prawo dla ubezpieczeń. Księga Jubileuszowa Profesora Eugeniusza Kowalewskiego, [red.] Bagińska E., Mogilski W., Wałachowska M., Ziemiak M., Toruń 2019.

Prawo konsumenckie w praktyce, Czarnecka M., Skoczny T. [red.], Legalis 2016.

Prawo ubezpieczeń gospodarczych. Komentarz. Tom II. Prawo o kontraktach w ubezpieczeniach. Komentarz do przepisów i wybranych wzorców umów, Brodecki Z., Glicz M., Serwach M. [red.], LEX 2010.

68. Por. Sz. Szmak, Dostęp obywateli do wymiaru sprawiedliwości - wybrane modele, „Rozprawy Ubezpieczeniowe" 2016, nr 22 (3), s. 77-89 oraz w wersji angielskiej: Sz. Szmak, Provision of legal services in Poland-free legal aid and legal expenses insurance as selected objects of the recent regulation, „Wiadomości Ubezpieczeniowe" 2016, nr 4, s. 115-125. 
Szmak K., Szmak Sz., VAT w kosztorysowej metodzie likwidacji szkód w autocasco, „Rzeczpospolita” 20.08.2013.

Szmak Sz., Dostęp obywateli do wymiaru sprawiedliwości - wybrane modele, „Rozprawy Ubezpieczeniowe" 2016, nr 22(3).

Szmak Sz., Provision of legal services in Poland-free legal aid and legal expenses insurance as selected objects of the recent regulation, „Wiadomości Ubezpieczeniowe” 2016, nr 4.

Szmak Sz., Ubezpieczenia ochrony prawnej w systemie niemieckim - wybrane problemy, „Wiadomości Ubezpieczeniowe" 2014, nr 2.

Szmak Sz., Ubezpieczenie ochrony prawnej w Polsce na tle regulacji niemieckich, TNOiK, Toruń 2018. Ustawa o działalności ubezpieczeniowej i reasekuracyjnej. Komentarz, Czablun P. [red.], Warszawa 2016, Legalis.

Ustawa o działalności ubezpieczeniowej i reasekuracyjnej. Komentarz, Szczepańska M., Wajda P. [red.], Warszawa 2017, LEX.

Wassiewicz A., Kowalewski E., Postulowany kształt umowy ubezpieczenia w Kodeksie cywilnym, „Państwo i Prawo” 1993, nr 11-12.

\section{Clauses excluding the insurance cover in a consumer legal expenses insurance contract - comments on the judgment of German Federal Court of Justice (Bundesgerichtshof) of 4 July 2018}

The article presents selected remarks on the judgment (case reference number IV ZR 200/16) passed on 4 July 2018 by German Federal Court of Justice in the matter of legal expenses insurance. The Court considered the clause excluding the insurance cover applied in model terms \& conditions of legal expenses insurance (ARB 2008) to be unclear and thus not binding to the consumer. On the occasion of this judgment, issues related to the term of an insured event were discussed, which is an essential concept for insurance practice. The presentation of the most important statements of the ruling is accompanied by comments on binding provisions of Polish law regarding the legal expenses insurance, the content of selected general terms and conditions of Polish legal expenses insurers, as well as the current jurisprudence of Polish Supreme Court as to the interpretation of the general insurance terms.

Key words: legal expenses insurance, insured event, insurance terms \& conditions, civil code, consumer protection.

DR SZYMON SZMAK - stypendysta Georg August Universität w Getyndze, licencjonowany broker ubezpieczeniowy, magister europeistyki; współpracuje z Katedrą Prawa Ubezpieczeniowego WPiA UMK w Toruniu.

e-mail: szymonszmak@gmail.com 